\title{
Liabilities of Queer Anti-Racist Critique
}

\author{
Stacy Douglas $\cdot$ Suhraiya Jivraj $\cdot$ Sarah Lamble
}

Published online: 9 July 2011

(c) Springer Science+Business Media B.V. 2011

\section{Introduction}

In September 2009, Raw Nerve Books, a small independent feminist publisher in Britain, issued a public apology to prominent gay right activist Peter Tatchell for content they had published in an edited collection titled, Out of Place: Interrogating Silences in Queerness/Raciality (2008b). ${ }^{1}$ It has been widely speculated that this apology was the result of a threat of legal action. ${ }^{2}$ The book contained an article critical of Tatchell's gay rights activism in Britain, arguing that some of his work contributes to larger patterns of racism and Islamophobia (Haritaworn et al. 2008). Both the article and book offered important and timely analysis of the ways that discourses of queerness and raciality have been silenced, displaced and marginalized within more dominant LGBTQ politics and human rights work.

The book had been initially scheduled for reprint following a sold out first run. However, in November 2009, amidst considerable controversy surrounding their

\footnotetext{
${ }^{1}$ The apology (dated August 2009) and a subsequent comment from the publishers (dated November 9) can be read at: http://www.rawnervebooks.co.uk/outofplace.html.

${ }^{2}$ Several authors have commented on the formal language of the apology as well as the pattern of formal apologies issued by other critics of Tatchell's strategies. See for example Newman (2010); Douglas (2010) as well as Ahmed's contribution and the roundtable discussion titled 'Queer Anti-Racist Activism and Strategies of Critique' in this issue.
}

\section{S. Douglas $(\square)$}

Kent Law School, University of Kent, Canterbury, UK

e-mail: S.M.Douglas@kent.ac.uk

\section{S. Jivraj}

School of Law and Social Sciences, Oxford Brookes University, Oxford, UK

e-mail: sjivraj@brookes.ac.uk

\section{S. Lamble}

School of Law, Birkbeck College, University of London, London, UK

e-mail: s.lamble@bbk.ac.uk 
earlier apology, Raw Nerve Books released a statement declaring that due to 'factual errors' and 'inaccuracies' in the book they had 'no alternative' but to refrain from republishing. ${ }^{3}$ As a result, the book is no longer available for re-ordering and, with no reprints in production, the authors and editors of Out of Place have become effectively subject to the same form of silencing they critique.

\section{The Politics of Queer Anti-Racist Critique}

As we followed the responses to the Out of Place controversy we were struck by how much was at stake. The disappearance of the book-one of the first edited collections in Britain on queerness and raciality - is itself a serious loss. Indeed, the Out of Place collection provided a significant contribution to wider practices of queer anti-racist critique. While we resist the notion of strictly defining what constitutes 'queer anti-racist critique', we characterise it in broad terms as a critical ethos or approach that refuses to separate questions of gender, sexuality, and queerness, ${ }^{4}$ from questions of raciality and racialisation. ${ }^{5}$ This form of intersectional critique serves as a tool for building spaces and movements that are committed to interrogating gender and sexuality norms, whilst simultaneously identifying, challenging, and countering the overt and embedded forms of racism that shape them.

\footnotetext{
${ }^{3}$ For a series of critical responses to the apology, see the contribution by Ahmed in this issue, as well as Rothe (2009), Erel and Klesse (2009), Aizura (2009) and Douglas (2010).

4 Although 'queer' is commonly used as an umbrella term for various sex/gender identities (i.e., lesbian, gay, bisexual, transgender, two-spirited, etc.), its roots also emerge from a critique of identity itself. Rather than trying to 'normalize' homosexuality in relation to heterosexuality (which is the aim of many rights-seeking projects), 'queer' seeks to question the norm itself and contest binary logics altogether (Butler 1993; Sedgwick 1990; Jagose 1996). For our purposes, 'queer' is a practice or way of doing things that challenges the logic of the norm. However, we also recognize that an overemphasis on queer 'as practice' can dangerously ignore the ways in which some bodies mark themselves or are marked as queer. Therefore, while wanting to maintain a conception of queerness 'as practice', we also want to attend to the importance of 'queerness' as experienced by particular bodies (e.g., gender non-conforming or sexually-dissident subjects). Finally, we also recognise the limits of 'queer' as a category itself, both in terms of the continuing debates about its use (and the historical and geographical specificity of the contexts in which it is evoked), and in terms of the inability of a single term to fully encapsulate the fluidity of people's multiple experiences and identity practices.

5 We use the terms raciality and racialisation to draw attention to the fact that race is not a static, fixed, essentialist or biological category, but instead an unstable and complex set of processes of individual, group and spatial categorisations. Theses processes of categorisation are informed by social, economic, historical and political factors which have been explored by critical race, postcolonial and anticolonial thinkers such as Goldberg (2001), Crenshaw et al. (1996) and Wing et al. (2003). We follow Jivraj and Herman in describing racialisation as a "form of understanding and way-finding-usually through phenotypical signifiers or characteristics-when encountering persons perceived as alien to the "home" environment' (Jivraj and Herman 2009). These phenotypical characteristics can be perceived to relegate the people possessing them to distinct and even inferior 'racial' or ethnic collectivities (Miles and Brown 2003, 100; Said 1978). However, these processes of racialisation are not only taken up in relation to phenotypical signifiers but also in relation to class, as well as embodied cultural and religious practices. For example, as Sherene Razack and others have pointed out, this form of 'race thinking' in the post 9/11 Euro-Atlantic context and the global 'war on terror', has come to mark minority religious identifications - and Muslims in particular - as racialised (Razack 2008). See also Brown (2006) and for critical race readings of representations of Jews and Jewishness in English law, Herman (2011).
} 
In the contemporary political landscape, the need for queer antiracist critique has perhaps never been greater. Sexuality, in the form of gay rights, ${ }^{6}$ is increasingly taken up by both liberal and conservative forces as a dominant marker of "western values,' which then serves as a key trope in the global war against terror ${ }^{7}$ and a pawn in the demise of even the most assimilationist notions of state multiculturalism. ${ }^{8}$ Whether we consider David Cameron's recent speech on 'muscular liberalism, 9 the emergence of a gay wing of the English Defence League, ${ }^{10}$ or the recent East End Gay Pride in London, ${ }^{11}$ the pitting of sexual diversity as a sign of modern civility against the 'backwardness' of certain forms of racialisation is a key problematic. ${ }^{12}$ Such examples demonstrate that this discourse not only comes from Conservative Prime Ministers and right-wing nationalist groups but also from local grassroots LGBT organisers. The currency of this discourse in LGBT organising itself is a topic further explored throughout this Special Issue. Significantly, as Puar and Ahmed both point out in their contributions, the use of gender and sexuality in the service of racist and imperialist agendas is not new, but its contemporary manifestations are deployed through novel modes and with reinvigorated force.

The critique of this problematic conjuncture between gay rights and racism has, of course, already been made many times. Indeed, Out of Place was one such example that assembled a broad body of work on this subject together in one collection. As such, the loss of the book reminds us that such events also mark a loss of energy and momentum required to articulate queer anti-racist critique in the first place. ${ }^{13}$ As Ahmed notes in her contribution, when such critiques are ignored, dismissed, or undocumented, the critic must start over; the critique must be made again. Yet in the aftermath of silencing, the conditions of critique become all the more difficult, not only because the space for articulation has been narrowed, but

\footnotetext{
${ }^{6}$ Our focus is on the confluence of gay rights and racism, but it is significant to note that these discourses also circulate in the defence of women's rights, especially for women who stand in as the racialised Others who are in need of saving through western imperialist interventionism. One can think here of Gayatri Spivak's popularly cited description of 'white men saving brown women from brown men' (Spivak 1988), which both Ahmed and Puar discuss in their contributions to this Special Issue. In Puar's words, "the "woman question" is now being supplanted with the "homosexual question"'(Puar 2011).

7 Much activist and academic work has been done exploring this conjuncture. In addition to the chapter 'Gay Imperialism' by Haritaworn et al., see also Haritaworn (2008), Kuntsman (2008a, 2008b), and Butler (2008).

8 See both Ahmed and Lentin's contribution to this Special Issue. For feminist, anti-racist critiques of state multiculturalism see Bannerji (2000), Yuval-Davis (1999), Bhandar (2009) and Fortier (2010).

9 David Cameron's speech, given in Munich on 5 February 2011 is available at: http://www. number10.gov.uk/news/speeches-and-transcripts/2011/02/pms-speech-at-munich-security-conference60293.

10 The English Defence League (EDL) is a far right, anti-Muslim group in England. For a discussion of the EDL's gay wing, see the Guardian's exposé (Taylor 2010) as well as commentaries by Gary Younge (2010) and Jasbir Puar (2010).

11 In March 2011, plans for a 'gay pride' march in East London were cancelled when it was revealed that organisers had links with the English Defence League and other anti-Muslim groups. See the Roundtable Discussion postscript in this issue for further details, as well as the Decolonize Queer statement (2011).

12 See for example, Puar (2007), Kato (2010), Douglas (2011) and Ekine and Ali (2010).

13 As noted in the introduction to Out of Place, the very capacity to articulate such critique in the first place was a struggle (Kuntsman and Miyake 2008a). See also the roundtable discussion in this issue.
} 
also because different kinds of labour and energy (physical, emotional, and affective) are required to make the critique yet again. The struggle against this on-going threat of fatigue and loss of momentum is just one example of what we want to highlight as a larger issue of 'liabilities of critique'.

We use 'liabilities of critique' to focus attention on the social, political, and economic consequences of articulating queer anti-racist critique. Indeed, our use of the term does not denote a strictly legal connotation of 'liability' (i.e., as in a tortious claim). ${ }^{14}$ Rather, we aim to intentionally displace this term from its legal framework in order to consider the costs of such critiques that are not captured by a juridical framing. Consequently, contributors to this Special Issue of Feminist Legal Studies explore what it takes to conceive of, assemble, defend, and bear the cost of queer anti-racist critique in academic and activist settings. Questioning the social, political, and economic conditions that inform, envelop, and stifle these critiques, this Special Issue examines the workings and formations of power relations that make some people more or less subject to the 'liabilities of critique'.

\section{Events, Responses and Dilemmas: Rethinking the Terms of Debate}

Reflecting on the broader implications of the loss of Out of Place, we wondered what would have been required for the events to unfold differently. Contemplating how we might respond, we faced a number of concerns and dilemmas. As academics and activists committed to queer antiracist critique, how should we enter the discussion and on what terms? Who might benefit from particular kinds of responses and who would not? What kind of collective responsibilities do we have to take up these issues and support those who make queer antiracist critique, particularly when some people have more to lose in the ensuing fallout than others? Below we elaborate on four key issues that imbued our thinking as we tried to conceive of how a queer anti-racist critique might further be brought to bear ${ }^{15}$ on the Out of Place events.

Firstly, we struggled with how to even talk about the Out of Place controversy. Indeed, what is at stake in the very language we choose to name and think through the event? How does describing it in particular terms or frameworks shape the possibilities for critique? We might consider, for example, the language used to describe different but related cases in other contexts, such as the public, professional, and even criminal reprisals against North American academics Sunera Thobani and Andrea Smith for their articulations of antiracist critique. ${ }^{16}$ In these

\footnotetext{
${ }^{14}$ There is of course overlap between a legal and lay usage of the term 'liability' in that people making critique who are subject to social and political liabilities can also face legal threats of libel. Although we do not take up the matter of legal reform here, British libel law has been recently subject to considerable reform efforts. See for example the English PEN and Index Libel Report (2009).

15 For a number of queer anti-racist responses to the events see footnote 3 .

16 Smith and Thobani have been subject to personal and professional attacks for their work, and in Thobani's case, threats of criminalisation. Although criminal charges never materialised, Thobani was subject to an investigation by the Royal Canadian Mounted Police for remarks she made at a conference in 2001, in which she criticised US foreign policy in and its 'war on terror' (Thobani 2002, Thobani
} 
cases, the events were framed as being primarily about 'censorship', 'freedom of speech', and 'academic freedom.' However, we were cautious of uncritically invoking these terms in the Out of Place case, not only for fear of implicitly valorising the liberal legal paradigm to which they belong, but also because such frameworks inevitably constrain the discussion within a prescribed set of concepts and debates.

For example, the aforementioned North American examples have been primarily characterised as matters of 'academic freedom'. ${ }^{17}$ As a result, the conversation often becomes about a subsequent issue-freedom of thought in the American academyrather then the initial anti-racist critique made by the individual in question. Moreover, the alluring paradigm of 'academic freedom' also invokes value-laden imaginations of justice that pivot on the attainment of universal rights. Yet, as Wendy Brown has argued, the assumed 'universality' behind any rights discourse ignores the power and potential of rights to empower people in different ways. Indeed as Brown states universally distributed rights can 'function not only as power but also as deprivation' (Brown 2002, 423). Brown's analysis is particularly relevant in this context, as the framework of 'academic freedom' pivots on an assumption about equal access to education that does not fully consider the socioeconomic issues that underpin the possibility of being an equal-rights bearer in the first place. As such, when the overarching argument becomes explicitly about 'academic freedom', the original anti-racist critique is not only subsumed by the subsequent discussion, but the very parameters of the discussion have a propensity to set the terms in liberal universal rights discourse. Our project of queer anti-racist critique aims to resist the limitations of this framing, by both recognising the importance of the original critique, as well as excavating the under-acknowledged power relations that shape our imaginations of justice. We therefore struggled over our ability to talk and think about the event in ways that corresponded with our vision of a queer anti-racist critique that takes these underlying issues into account.

Secondly, we found it difficult to respond to such events in ways that attended to the specificity of the circumstances, while also recognising the broader relations of power that enable such events to occur. On the one hand, there is a tendency to treat these situations as single, one-off events. In the case of the Out of Place controversy, news stories, blog posts, and Tatchell's own response discussed the incident in conventional journalistic style, reporting a singular news event by relaying the 'objective' details of the case. ${ }^{18}$ However, critical cultural studies theorists and media scholars have long explored the ways in which journalistic

\footnotetext{
Footnote 16 continued

2003). For a discussion of Smith's case, see Cotera (2010). More generally see McLaren, Best and Nocella (2010), and the special themed issues of Social Text (Schueller and Dawson 2007), the British Journal of Educational Studies (Hayes 2009) and Critique: Journal of Socialist Theory (Ticktin 2009).

17 For further discussion of the prevalent discourse of 'academic freedom', especially in the North American context, see Haritaworn's comments in the roundtable discussion as well as the references in footnote 19 .

18 See for example the media coverage in the Pink Paper (Marvin 2009) and Pink News (2009) as well as Peter Tatchell's own press releases (Tatchell 2009).
} 
accounts of stories orient the readers' attention to a particular narrative. ${ }^{19}$ Often such descriptions present such events as isolated incidents with no links to similar historical occurrences or patterns. For example, when The Pink Paper and Tatchell reported on the Raw Nerve apology, it was characterised as a one-off event. This framing distanced the event from within a broader context of critiques questioning the racial politics of Peter Tatchell's gay rights activism. ${ }^{20}$ For us, one of the key imperatives of queer anti-racist critique is understanding how events might fit into larger patterns of systemic racism. Queer anti-racist critique must resist treating these events as isolated occurrences, and instead make connections where individual events are linked to historic legacies of racism.

On the other hand however, when such events are situated within a longer historical narrative, they are often framed in ways that miss the complexity of the specific conditions and power relations that give rise to the event itself. Indeed, in some instances the Out of Place controversy was not treated as a one-off event, but as part of a longer narrative of hate and smear directed against Tatchell. ${ }^{21}$ In this framing, there is recognition of historical contingency but the narrative tells a very particular story-in this case, the story of an innocent community activist being attacked by intellectuals. What is significant here for queer anti-racist critique is how these narratives mask the social, economic and political conditions of who can speak and on what terms. ${ }^{22}$

In the case of Out of Place, the authors, who were challenged by Tatchell and his supporters, were unable to re-insert into the debates what had been missed or left out of particular narratives. This was largely due to the ever-present threat of legal action-an issue of particular concern in the UK context. ${ }^{23}$ Indeed, several parties directly involved were unable to speak to others about the specific details of the case, or to speak about the threat of legal action at all. ${ }^{24}$ The instigator of the legal threat holds the economically and legally privileged position to speak publicly about

\footnotetext{
19 See for example Hackett and Carroll (2006), Hall et al. (1978), Hugill (2010), and White (White 1984).

20 See for example African LGBTI Human Rights Defenders (2007), Livingstone (2005), and Long (2009).

21 See T., David (2009) as well as Tatchell in footnote 18 above.

22 For example, the events surrounding Raw Nerve and 'Out of Place' were the subject of a panel at the 'Dissident Citizenship: Queer Postcolonial Belonging' conference held at the University of Sussex in June 2010. The panel, which was set up by the Brighton and Sussex Sexualities Network, played out as a 'pro and con' debate about the article, a structure that made it difficult to discuss the complexities of the event and its fall-out. This conference is also mentioned in the activist roundtable discussion included in this Special Issue.

${ }^{23}$ UK libel law is remarkably supportive of complainants, putting the burden of proof on the defendant. As Dan Hind, author of The Return of the Public (Verso 2010), writes: 'The plaintiff doesn't even have to prove that a claim is untrue. The defendant must be able to establish in court that a claim is true. And he or she has to do this with primary sources-sworn witness statements, testimony in court. The game is rigged to make it all but impossible to say anything substantial about any powerful individual or institution without running eye-watering risks' (Hind 2010). In such cases, it is most often smarterfinancially and legally - to retract and apologize, rather than risk going to trial on uncertain legal terms.

24 This topic is further explored in the roundtable discussion. See also the recent case of Spiller v Joseph [2010] UKSC 53. Lord Phillips renamed and expanded the scope of the defence of fair comment to 'honest comment'. This change now reduces the burden on defendants to identify facts they are
} 
the case as any further public announcements made by the defendant can be used against them in a potential libel suit. ${ }^{25}$ In such cases, the instigator may discuss details of the case in public settings, including with the press, while the defendant and their supporters are effectively silenced through legally instantiated economic coercion. This conundrum poses real problems when attempting to read and write about such events in ways that take into consideration the myriad socio-economic forces, and political risks at play.

Thirdly, we were challenged to think how we could draw attention to the oftenunseen material costs of queer anti-racist critique. By material costs, we were thinking particularly of the social, economic and emotional labour required both to make the critique in the first place as well as to respond to the subsequent fall-out. We were also thinking of the way that the risks of articulating critique (i.e., losing one's job or organisational funding, facing a lawsuit, being labelled as a troublemaker, etc.) can be unevenly distributed. Certainly, due to already existing socio-economic conditions, some people have more to lose than others. This is often the case for precarious academic workers, particularly those without a permanent position or departmental support, who can expect to face the full legal and economic force of the fallout by themselves. As outlined in both the roundtable discussion and Jivraj and de Jong's contribution herein, this is also a key concern for those working within small grassroots organisations such as the Safra Project in the UK or Merhaba in Belgium that organise around issues of sexuality and racialisation. The informal and undocumented ways in which such organisations operate with little, if any, funding or institutional support often remains unrecognised. Yet if we are concerned about the conditions that limit and constrain queer anti-racist critique, it is important to attend to the social, economic and personal costs of articulating those critiques.

Lastly, as we contemplated how to respond, we considered the pitfalls of privileging 'voice' in articulating critique. Although one of the central aims of this Special Issue is to document the stifling of certain forms of critique, we also question the assumption that speaking necessarily equals emancipation, or that articulation is a precondition for remedying injustice. For example, as Jivraj and de Jong argue in their contribution, the presumption that gay liberation must be performed through the public articulation of one's sexuality (i.e., being 'out and proud') privileges a narrow idea of what it means to be a 'gay' subject, thereby denying or erasing the multiple other ways that such sexualities can be lived or inhabited. The assertion of some identity practices as more authentic than others works to regulate and discipline subjects into conforming to the norms of the proper sexual subject.

Moreover, some feminist theorists have drawn attention to the problems of invoking a politics of 'voice' or 'breaking silence' for its oft unseen attachment to naturalised and essentialist ideas of the subject that can then authentically speak

\section{Footnote 24 continued}

commenting on with 'sufficient particularity' [see further Rhind's (2010) Case Comment]. Lord Phillips also called on the Law Commission to consider and review the present state of the defence.

25 See English PEN and Index Report (2009) noted above in footnote 14. 
truth about their experiences of injustice. ${ }^{26}$ Indeed, these critiques draw attention to the potentially dangerous implications of these politics for their deployment of a concept of the subject that relies upon, and desires to return, to a natural whole. Of course, such a concept ignores the scholarship of queer and anti-racist theorists who have repeatedly problematised this notion of the subject. ${ }^{27}$ These scholars have claimed that this authentic subject is an imagined one and that it is better understood as inherently contingent, fragmented, and incomplete, rather than 'naturally' whole.

However, while taking seriously critiques of 'authenticity' and the privileging of breaking silence, we also wish to push these theories further to consider the competing functions of racism and power as they come to bear on individuals and organisations. As this editorial and multiple contributions indicate, despite a problematised notion of the naturalised subject, the forces of legal coercion, unequal wealth distribution, and precarious employment situations continue to threaten those who utter particular forms of critique with social, economic, and carceral penalties. $^{28}$ These liabilities of critique demand political and philosophical attention. It is our contention that queer anti-racist critique can simultaneously surface the unseen costs, consequences, and conditions of critique, while resisting an essentialist identity politic that deploys claims to 'authenticity'. The articles contained herein are an attempt to straddle these concerns by attending to both the necessity of articulating critique as well as the problems of doing so.

\section{Special Issue Outline}

In 'Problematic Proximities: Or why Critiques of Gay Imperialism Matter', Sara Ahmed begins with the censorship of Out of Place and likens the recurring pattern of this, and similar events, to a well-rehearsed script. These scripts not only allow racism to circulate, but also prevent critiques of racism from being addressed. Further, Ahmed considers how particular signs and symbols of language draw 'problematic proximities' between terms, stringing along silent associations with their 'stickiness'. Ahmed's contribution further elucidates a key problematic highlighted in the editorial - the difficulty of language in both talking about and producing racism. She also introduces an important consideration of the affective qualities of racist speech and how language is embroiled in larger national and transnational politics, such as in the 'war on terror'.

In 'Censorship and Citation: The Politics of Talking About the Sexual Politics of Israel', Jasbir Puar also considers the confluence of racism and national politics.

\footnotetext{
${ }^{26}$ We are thinking here of critiques launched by Berlant (2002) and Brown (2005).

27 See Berlant and Brown above, as well as Judith Butler (1997), Paul Gilroy (2004) and Stuart Hall (1997).

28 We are thinking of cases where individuals have been imprisoned either directly or indirectly for their anti-racist activities. See for example, writings on the incarceration of members of the Black Panther and American Indian Movement (e.g., Churchill and Vander Wall (2002), Saleh-Hanna and Alston (2007), Shakur (1987) and Davis (1974/1990)).
} 
However, rather than focus explicitly on language, Puar's site of exploration is the phenomenon of what many have referred to as 'Israeli pinkwashing'. ${ }^{29}$ Specifically, Puar analyses the current Israeli-sponsored campaign to rebrand itself as a harbinger of sexual diversity and tolerance for gay rights. She argues that as the campaign conflates tolerance of gays with liberal-democracy, it produces and relies upon colonial stereotypes of Palestinians as anti-gay and, therefore, inherently premodern. This piece is based on the text of a lecture given at Humboldt University in December 2010 with an introduction in which the author outlines how the original title, 'Beware Israeli Pinkwashing', generated controversy in Berlin and was subjected to censorship attempts. The piece is significant for the Special Issue, not only in providing an example of the kinds of queer anti-racist critique that have been silenced or marginalized, but also in outlining the broader political context of 'homonationalist' trends, a pattern that many of these critiques seek to challenge.

Building on a critique of homonationalism, Suhraiya Jivraj and Anisa de Jong explore the ways that nationalist sentiment around a history of promulgating gay rights in the Netherlands can work to silence queer Muslims and curtail queer antiracist critique. Their article, 'The Dutch "Homo-Emancipation" Policy and its Silencing Effects on Queer Muslims', demonstrates how social policies which aim to promote gay tolerance within targeted 'minority' communities, ironically create conditions where it is more difficult for queer Muslims to articulate, address and organise on issues of race and sexuality. They argue that in the Dutch context, the state-backed emphasis on the utterance of queerness, in other words, being 'out' with one's sexuality, functions to marginalise other ways and modes of inhabiting queer Muslim sexualities.

Finally, in 'What Happens to Antiracism When We Are Post Race?' Alana Lentin argues that the problematisation of race put forward by anti-racist activists and scholars has been displaced by a 'postracial' agenda that downplays experiences of racism. As such, Lentin claims that many self-declared anti-racists actively participate in what she terms the 'appropriation' of the experience of racism. In this article, Lentin charts the landscape of this history of appropriation and its confluence with state-backed agendas of 'diversity inclusion' to point to the ways in which claims of 'antiracism' have been pitted against each other. Lentin's piece provides some historical context to the discussion of academic and activist antiracist critique and, in addressing the continued legacies of racism that imbue these discussions, highlights the importance of thinking through what we mean by 'critique'.

The Special Issue also includes a roundtable discussion that brings together grassroots activists and academics who are involved in transnational queer antiracist work. The roundtable includes Jin Haritaworn and Tamsila Tauqir, two of the authors of 'Gay Imperialism' in the Out of Place collection, and both of whom are involved in transnational queer anti-racist activism. The roundtable also includes Sokari Ekine, Jen Petzen, and Sarah Bracke, who are each engaged in activist work in multiple contexts, but with particular focus on Nigeria, Germany and Belgium,

\footnotetext{
${ }^{29}$ See for example Palestinian Queers for BDS: http://pqbds.wordpress.com/2011/02/23/an-open-letterto-queer-academics-artists-and-activists/
} 
respectively. The roundtable moves the discussion explicitly to the realm of social movement politics as it discusses key factors that contribute to the silencing of antiracist queer activism, as well as avenues for resistance. The participants share rich and important insights on transnational alliance building, funding, self-care, and the problems of trying to articulate critique in the first place.

We believe that this Special Issue brings together a number of important contributions to the genealogy and intellectual force of queer anti-racist critique. In so doing, we hope to make a significant contribution to the thinking of 'queerness' and 'anti-racism' together for both activist and academics alike.

Acknowledgments This Special Issue is dedicated to Ugandan gay rights activist David Kato (1964-2011).

\section{References}

African LGBTI Human Rights Defenders. 2007. Public statement of warning. Monthly Review Zine. http://mrzine.monthlyreview.org/2007/increse310107.html Accessed 1 May 2011.

Aizura, Aren Z. 2009. Racism and the censorship of 'Gay Imperialism'. Monthly Review Zine. http:// mrzine.monthlyreview.org/2009/aizura231009.html Accessed 1 May 2011.

Bannerji, Himani. 2000. The dark side of the nation: Essays on multiculturalism, nationalism and gender. Toronto: Canadian Scholars' Press.

Berlant, Lauren. 2002. The subject of true feeling: pain, privacy, and politics. In Left Legalism/Left Critique, ed. W. Brown, and J. Halley. Durham \& London: Duke University Press.

Bhandar, Brenna. 2009. The ties that bind: Multiculturalism and secularism reconsidered. Journal of Law \& Society 36(3): 301-326.

Brown, Wendy. 2002. Suffering the paradoxes of rights. In Left Legalism/Left Critique, ed. W. Brown, and J. Halley. Durham \& London: Duke University Press.

Brown, Wendy. 2005. Freedom's silences. In Edgework: Critical essays on knowledge and politics. Princeton and Oxford: Princeton University Press.

Brown, Wendy. 2006. Regulating aversion: Tolerance in the age of identity and empire. New Jersey: Princeton University Press.

Butler, Judith. 1993. Bodies that matter: On the discursive limits of "sex". New York and London: Routledge.

Butler, Judith. 1997. The pscychic life of power: Theories in subjection. Palo Alto: Stanford University Press.

Butler, Judith. 2008. Sexual politics, torture and sexual time. The British Journal of Sociology 59(1): $1-23$.

Churchill, Ward., and Jim. Vander Wall. 2002. Agents of repression: The FBI's secret wars against the Black Panther Party and the American Indian movement. Cambridge: South End Press.

Cotera, Maria.E. 2010. Women of color, tenure, and the neoliberal university. In Academic repression: Reflections from the academic industrial complex, ed. A.J. Nocella, S. Best, and P. McLaren. Oakland, California: AK Press.

Crenshaw, Kimberle., Neil. Gotanda, Gary. Peller, and Kendall. Thomas (eds.). 1996. Critical race theory: The key writings that formed the movement. New York: New press.

Davis, Angela. 1974/1990. An autobiography. London: The Women's Press.

Decolonise Queer. 2011. From Gay Pride to white pride? Why marching on east London is racist. http:// www.decolonizequeer.org/?p=1 Accessed 1 May 2011.

Douglas, Stacy. 2010. On defending raw nerve books, or, the stuff of good feeling. Upping the Anti: A Journal of Theory and Action 11: 115-127.

Douglas, Stacy. 2011. Beyond barbarism: David Kato, Uganda and the American right. Critical Legal Thinking. http://www.criticallegalthinking.com/?p=2001 Accessed 1 May 2011.

Ekine, Sokari, and Muna Ali. 2010. African Perspectives: Interview with Sokari Ekine. 11 July. http:// www.archive.org/details/AfricanPerspectivesSokariEkine Accessed 1 May 2011. 
English PEN, and Index on Censorship. 2009. Free speech is not for sale: The impact of english libel law on freedom of expression. http://libelreform.org/reports/LibelDoc_MedHiRes.pdf Accessed 24 January 2011.

Erel, Umut, and Christian Klesse. 2009. Out of Place: silencing voices on queerness/raciality. Monthly Review Zine. http://mrzine.monthlyreview.org/2009/ek241009.html Accessed 1 May 2011.

Fortier, Anne.-Marie. 2010. Proximity by design? Affective citizenship and the management of unease. Citizenship Studies 14(1): 17-30.

Gilroy, Paul. 2004. After empire: Melancholia or convivial culture?. London and New York: Routledge.

Goldberg, David.Theo. 2001. The racial state. Oxford: Blackwell.

Hackett, Robert.A., and William.K. Carroll. 2006. Remaking media: The struggle to democratize public communication. London: Routledge.

Hall, Stuart. 1997. Race: A floating signifier? [Film]. Media education foundation, available at: www. medied.org/.

Hall, Stuart., Charles. Critcher, Tony. Jefferson, John. Clarke, and Brian. Robert. 1978. Policing the crisis: Mugging the state and law and order. London: Palgrave Macmillan.

Haritaworn, Jin. 2008. Loyal repetitions of the nation: Gay assimiation and the 'War on Terror'. Darkmatter 3. Accessed 1 May 2011.

Haritaworn, Jin., Tamsila. Tauqir, and Esra. Erdem. 2008. Gay imperialism: Gender and sexuality discourse in the "War on Terror'. In Out of Place: Interrogating silences in Queerness/Raciality, ed. A. Kuntsman, and E. Miyake. York, England: Raw Nerve Books.

Hayes, Dennis, ed. 2009. Academic freedom. Special Issue, British Journal of Educational Studies. 57 (2).

Herman, Didi. 2011. Jews and Jewishness in english law. Oxford: Oxford University Press.

Hind, Dan. 2010. Libel law should protect the public, not the powerful. The Guardian Sept 17. Accessed 1 May 2011.

Hugill, David. 2010. Missing women, missing news: Covering crisis in vancouver's downtown eastside. Winnipeg: Fernwood.

Jagose, Annamarie. 1996. Queer theory: An introduction. New York: New York University Press.

Jivraj, Suhraiya., and Didi. Herman. 2009. 'It is difficult for a white judge to understand': Orientalism, racialisation, and christianity in english child welfare cases. Child and family law quarterly 21(3): 283-308.

Kato, David. 2010. A matter of life and death: the struggle for ugandan gay rights. public lecture. March 17. kent centre for law, gender and sexuality. Canterbury UK: Kent Law School.

Kuntsman, Adi. 2008a. Queerness as Europeannness: Immigration, orientalist visions and racialized encounters in Israel/Palestine. Darkmatter 3. http://www.darkmatter101.org/site/2008/05/02/ queerness-as-europeanness-immigration-orientialist-visions-and-racialized-encountersin-israelpalestine/.

Kuntsman, Adi. 2008b. The soldier and the terrorist: Sexy nationalism, queer violence. Sexualities 11(1-2): 142-170.

Kuntsman, Adi., and Esperanza, Miyake. 2008a. Introduction. In Out of Place: Interrogating silences in Queerness/Raciality, ed. A. Kuntsman, and E. Miyake. York, England: Raw Nerve Books.

Kuntsman, Adi., and Esperanza, Miyake (eds.). 2008b. Out of place: Interrogating silences in Queerness/ Raciality. York, England: Raw Nerve Books.

Livingstone, Ken. 2005. Tatchells islamic conspiracy theory. Labour left briefing. http://www. islamophobia-watch.com/islamophobia-watch/2005/2/14/tatchells-islamic-conspiracy-theory. html Accessed 1 May 2011.

Long, Scott. 2009. Unbearable witness: How western activists (mis)recognize sexuality in Iran. Contemporary Politics 15(1): 119-136.

Marvin, Emma. 2009. Tatchell accused of censorship in book row. The Pink Paper November 2. http:// news.pinkpaper.com/NewsStory.aspx?id=1912 Accessed 1 May 2011.

McLaren, Peter., Steven. Best, and Anthony.J. Nocella (eds.). 2010. Academic repression: Reflections from the academic industrial complex. Oakland: AK Press.

Miles, Robert., and Malcolm. Brown. 2003. Racism. London: Routledge.

Newman, Andy. 2010. Did Peter Tatchell uses [sic] libel laws to delegitimise criticism? http:// www.socialistunity.com/?p=6218 Accessed 1 May 2011.

Pink News Staff Writer. 2009. Peter Tatchell accuses academics of smearing him. Pink News November 3. http://www.pinknews.co.uk/2009/11/03/peter-tatchell-accuses-academics-of-smearing-him/ Accessed 1 May 2011. 
Puar, Jasbir K. 2007. Terrorist assemblages: Homonationalism in queer times. Durham \& London: Duke University Press.

Puar, Jasbir K. 2010. To be gay and racist is no anomaly. The Guardian (June 2). http://www. guardian.co.uk/commentisfree/2010/jun/02/gay-lesbian-islamophobia Accessed 1 May 2011.

Puar, Jasbir. 2011. Citation and censorship: The politics of talking about the sexual politics of Israel. Feminist Legal Studies. doi:10.1007/s10691-011-9176-3

Razack, Sherene. 2008. Casting out: The eviction of Muslims from western law and politics. Toronto: University of Toronto Press.

Rhind, Catherine. 2010. Case comment: Spiller v Joseph and others [2010] UKSC 53. http:// ukscblog.com/case-comment-spiller-v-joseph-2010-uksc-53 Accessed 10 June 2011.

Rothe, Johanna. 2009. Out of Place, out of print: on the censorship of the first queerness/raciality collection in Britain. Monthly Review Zine. http://mrzine.monthlyreview.org/2009/rothe151009.html Accessed 1 May 2011.

Said, Edward. 1978. Orientalism. New York: Pantheon.

Saleh-Hanna, Viviane, and Ashanti Omowali Alston. 2007. Special anniversary issue: Black panther party 1966-2006. Journal of Prisoners on Prisons. 15 (2).

Schueller, Malini Johar, and Ashley Dawson, eds. 2007. The perils of academic freedom. Special Issue, Social Text. 25 (1).

Sedgwick, Eve.Kosofsky. 1990. Epistemology of the closet. Berkeley: University of California Press.

Shakur, Assata. 1987. Assata: An autobiography. Chicago: Lawrence Hill Books.

Spivak, Gayatri Chakravorty. 1988. Can the subaltern speak? In Marxism and the interpretation of culture, ed. C. Nelson, and L. Grossberg. Houndmills, Hampshire: Macmillon Education Ltd.

David, T. 2009. Defend peter Tatchell. Harry's place. http://hurryupharry.org/2009/11/01/defend-petertatchell/ Accessed 1 May 2011.

Tatchell, Peter. 2009. Academics smear Tatchell. http://www.petertatchell.net/politics/academics-smearpeter-tatchell.htm Accessed 1 May 2011.

Taylor, Matthew. 2010. English defence league: New wave of extremists plotting summer of unrest. The Guardian May 28 (May 28). http://www.guardian.co.uk/uk/2010/may/28/english-defence-leagueprotest-bnp Accessed 1 May 2011.

Thobani, Sunera. 2002. War Frenzy. Meridians 2(2): 289-297.

Thobani, Sunera. 2003. War and the politics of truth-making in Canada. International Journal of Qualitative Studies in Education 16(3): 399-414.

Ticktin, Hillel, ed. 2009. Freedom of speech. Special Issue, Critique: Journal of Socialist Theory. 37 (4).

White, Hayden. 1984. The question of narrative in contemporary historical theory. History and Theory 23(1): 1-33.

Wing, Adrien., Richard. Delgado, and Bell. Derek (eds.). 2003. Critical race feminism: A reader. New York: New York University Press.

Younge, Gary. 2010. Gay equality can't be claimed a western value, but it is a human right. The guardian (June 7). http://www.guardian.co.uk/commentisfree/2010/jun/07/racism-islamophobia-homophobiafar-right Accessed 1 May 2011.

Yuval-Davis, Nira. 1999. Ethnicity, gender relations and multiculturalism. In Race, identity and citizenship: A reader, ed. R.D. Torres, L.F. Mirón, and J.X. Inda. Oxford: Blackwell. 